\title{
Air Power Projection in Conduct of NATO Deterrence Activities and Operations
}

\author{
Goran BOROŠ ${ }^{1 \oplus}$ - János CSENGERI ${ }^{2 \oplus}$
}

\begin{abstract}
This paper provides an overview and analysis of the role, place and importance of air power for the success of joint military operations in conduct of NATO deterrence activities and operations. Air power has been highly valued in defence, security and in warfare from its very beginning, since the establishment of the first Air Forces. With its modern development it has become crucial for achieving military goals, as well as national ones. The importance of air power is shown through its definition and comparison in the military doctrines of the air forces of certain countries and NATO, where it is obvious how important it is in the structure of national power, security and defence, as well as in collective security and defence of NATO. The emphasis is on the ongoing implementation of NATO military activities and operations and the projection of the Alliance's air power in deterring Russia's potential threats to its members in Northeast Europe, in the Baltic region. The current method of projection of air power and the use of its elements in these NATO military activities are discussed and presented. The special features and capabilities provided by the air power, which do not possess other military components and cannot compensate for these effects, give it a key role in supporting and conducting joint military operations, and in enabling the success of their implementation.
\end{abstract}

Keywords: air power, air force, NATO, joint operations, deterrence, air force doctrine, power projection

\section{Introduction}

The technological development of military aviation after World War II to date has gradually but greatly improved the capabilities of the air component of the armed forces. The air power nested in the air components of armies, of course depending on abilities in harnessing power, the composition and number makes it an indispensable ability in conducting military operations and warfare.

Major, Lecturer, Croatian Defence Academy; e-mail: goran.boros@morh.hr

PhD, Assistant Professor, University of Public Service Faculty of Military Science and Officer Training;

e-mail: Csengeri.Janos@uni-nke.hu 
'If we lose the war in the air, we lose the war, and we lose it quickly.' Bertrand Law Montgomery ${ }^{4}$

A statement made by Field Marshal Montgomery, while combating Germans in North Africa during World War II, vividly demonstrates the importance of air superiority for warfare success.

In the time after World War II, the development of the aircraft's performance, along with the evolution and use of jet engines, were supplemented by further possibilities, such as equipping with more modern weapons. The ability to use missiles, even at the time after World War II, as the main capability that enabled the use of nuclear weapons, meant an increasingly significant ability to project military power through air or more specifically, air force. In addition, the modernisation of aircraft with technologies for orientation, manoeuvre and defence, has made it possible to reduce the number of crew. ${ }^{5}$

As the characteristics of aviation grew, in a way they assumed the effectiveness of rapid action ahead of other components of the armed forces. Basic characteristics such as speed, range and altitude from which air forces can operate and deliver air power, are some of the key features for achieving military objectives. ${ }^{6}$ The further development of technology and its application in military aviation, from the last decades of the $20^{\text {th }}$ century to the present day, has improved aircraft with electronic systems of battle and defence, so-called stealth technology and "smart" weapons. This further and greatly strengthened the strategic potential of air power. As military air operations have also been developed for joint action with ground forces, this has reduced the use of ground forces over time by enhancing actions and providing freedom of manoeuvre.

The possibilities of aviation in the conduct of operations are in the air, over water surfaces and seas and on land targets with other military components (land and maritime) which are defined as joint operations. The developed capabilities of aviation for the transport of personnel and cargo, as well as electronic reconnaissance and surveillance of aerosphere and data collection, must not be left out. In addition, the possibilities are not limited to aerial and surface actions, their range is wider, such as space and the cybernetic domain. Air power, therefore, has comprehensive definitions, such as the one nested in the NATO Alliance's doctrinal documents: "The ability to use air capabilities to influence the behavior of actors and the course of events."

The aim of this article is to present the capabilities and importance of air power in the implementation of military activities and operations. Special focus is on NATO air activities and operations that project its air power in the implementation of current activities of assurance and deterrence of the potential threats to its Northeastern European

3 UK Ministry of Defence’s Development, Concepts and Doctrine Centre, 'An introduction to UK air power', in Joint Doctrine Publication 0-30 UK Air and Space Power, ( $2^{\text {nd }}$ Edition, 2017), 2.

$4 \quad$ Field Marshall Bernard Law Montgomery (1887-1976), former Commander of British Army Groups in World War II, Chief of the Imperial General Staff and NATO Deputy Supreme Allied Commander Europe.

Karl P Mueller, ‘Air Power’, in RAND Project Air Force (John Wiley and Sons, Ltd., 2010).

$6 \quad$ Lieutenant Colonel Johnny R Jones, ‘Air Power’, United States Air University Journal.

Mueller, 'Air Power'.

$8 \quad$ NATO, Allied Joint Publication, 'Fundamentals of Joint Air Power', in NATO Standard AJP-3.3. Allied Joint Doctrine for Air and Space Operations, Edition B Version 1 (NATO Standardization Office, 2016), 1-2. 
members of the Alliance, which ultimately, in line with NATO's cornerstone which is collective defence, represents the protection and assurance of the Alliance as a whole.

To process the topic and achieve the goal of this paper, the method of analysis of selected national and NATO military doctrines that contain guidance on employing air power, available publications that include the analysis of air power and means for enabling its employment, as well as data on the implementation of NATO military air activities in Northeast Europe, was used. The first part of this paper presents an overview of definitions, roles and areas of air power implementation defined in military doctrines. The second part provides a description of NATO military air activities and operations on its northeast flank but also throughout the member states' airspace, as a projection of air power. The conclusion provides an assessment and significance of the effects of NATO's implementation of these military air activities.

\section{Air power through military doctrines}

The evolution and strengthening of military air capabilities are accompanied by doctrines that describe and define air power and provide core guidelines for its use. The military doctrines of the air forces are close in defining air power.

The United States Air Force Doctrine defines air power as “the ability to project military power or influence through the control and exploitation of air, space, and cyberspace to achieve strategic, operational, or tactical objectives". ${ }^{9}$ The development of technological capabilities of air power is related to the recognition and the need to act in domains other than solely aerial in order to achieve national goals at all levels.

The United Kingdom doctrine of Air and Space Power portrays air power as one of the elements, combined with land, naval, space and cyber forces, which constitute the totality of military power and are one of the key factors of national power. It defines air power as "using air capabilities to influence the behaviour of actors and the course of events". ${ }^{10}$

"Air power is that element of military power applied within or from the air environment to create effects above, on, and below the surface of the Earth," ${ }^{11}$ is how Canadian air force doctrine specifies air power. The Air Force, which projects air power, together with other components of the Canadian Army presents a significant factor in Canada's national security system and in protection of national interests.

The Australian air force doctrine cites air power as a vital force, which, together with other parts of the military, contributes to national power. Their doctrinal definition presents air power as: “The ability of a nation to assert its will by projecting military power in, through and from the air domain." 12 Air power is a factor that contributes to

9 Curtis E LeMay Center, 'Basic Doctrine’, in United States Air Force Doctrine (Maxwell, 2015).

10 UK Ministry of Defence’s Development, Concepts and Doctrine Centre, 'An introduction to UK air power', 5.

11 Canadian Forces Aerospace Warfare Centre, 'Air Power Doctrine’, in Royal Canadian Air Force Doctrine (2015), 1-1.

12 Royal Australian Air Force Air Power Development Centre, 'Fundamentals of Air and Space Power', in The Air Power Manual (Australian Air Publication, 2013), 121. 
national security, with the role of supporting and enabling the action of other subjects of national power.

All of the above listed and presented notions from military doctrines depict a similar understanding and emphasise the role, importance and contribution of air power to national strength, national defence, and to the pursuit of national interests. Looking from a military aspect, the doctrines provide fundamental guidelines for the use of air power in military activities and operations and refer to the operational principles and employment of air power in various types of military operations.

The guidelines set out the principles of air operations and the use of air power in autonomous air operations, air support operations to other military components and in joint operations together with other military components (land and naval), for the purpose of achieving military and political goals. Furthermore, in addition to the use of air power for national purposes, they set rules and conditions for participation in joint coalition and international operations.

NATO Allied Joint Doctrine for Air and Space Operations, whose definition of air power has already been presented, consolidates the principles for conducting air operations as part of joint multinational Allied operations, and thus defines the use of air power, which is accepted by all thirty member states of the Alliance. It also emphasises the advantages of using air power due to speed, long range and the ability to act from a height, and defines the key roles of air power and the types of air operations by which it should be projected. Primarily for the defence, and then for the protection of the interests of the Alliance, the role of air power serves to achieve goals at all military and political levels through, counter-air (protection of air domain through defensive or offensive operations), attack, air mobility and contribution to intelligence, surveillance and reconnaissance operations as well as support to joint personnel recovery. The conduct of these operations is also a large enabler for the effective manoeuvre of other military components participating in joint multinational Allied activities and operations. ${ }^{13}$ Having said this, it should be noted that aspects and capabilities vested in air operations are extremely valuable input and part of the planning of all joint military operations.

As already mentioned, air force capabilities have been developed to operate through the air, space and cyber domains. As it is commonly known, air power can be delivered by means such as fixed and rotary wings combat and transport aircraft, reconnaissance surveillance and electronic aircraft, unmanned aerial aircraft, etc., which are parts of airborne capability within the overall air power composition.

The elements that determine the overall concept of the air force are the composition of airborne elements, effective command and control system, an industry that can meet specific requirements, supporting electronic systems, air bases, quality personnel and their training, strategic guidelines, effective planning, developed intelligence gathering system and timely and effective logistic support. ${ }^{14}$

NATO, 'Fundamentals of Joint Air Power', 1-1-1-18.

14 Sanu Kainikara, 'What Constitutes Air Power?', in Pathfinder Collection Volume 9, ed. by Sanu Kainikara (Canberra: Australian Air Power Development Centre, 2019), 23-26. 
Although the whole air power system is very demanding in design and quite expensive in production and maintaining, the performance capabilities obtained, which are manifested through speed, accuracy and long-range efficiency in individual and synergistic action with other military components, emphasise the indispensable role and very often the primacy of air power projection in conducting and supporting military operations.

\section{Forward basing as a means of air power projection}

Even though projecting military power can be conducted in several ways and by any means, one of the most regular methods is establishing or to be hosted in base(s) in the partner or allied countries. Even air forces need bases around or within the specific area of operation in order to enhance their range, time on target and responsiveness.

If we are looking for a more scientific (but even more theoretical) background of establishing overseas bases, the 'loss-of-strength gradient' can be mentioned which was created and explained by Kenneth E Boulding in 1962. He said, and explained his theory through complex mathematical formulas, that the further we go and the longer the chain of supply is, the more strength we lose compared to that strength we could utilise from our home bases during a conflict near us. ${ }^{15}$

The critics of this theory, even Boulding in his next book ${ }^{16}$ said that by the utilisation of modern weapon systems like missiles, strategic bombing aircraft and solutions like rapid global airlift eliminate the significance of this idea. Nevertheless, the former facts exist; these assets cannot apply in every case.

Conflicts of our days proved that centres of gravity are not always easy to determine or almost impossible. Fighting against a hiding, irregular or harassing adversary necessitates much more time on target and constant air presence. Hence, to realise a constant air presence, one needs to project its military power, including air power to overseas or forward-deployed military bases.

Even if the model is insular or simplistic, the basic idea is valid; it is enough if we take a look at the praxis in the conflicts of the $20^{\text {th }}$ century:

- American aircraft were deployed into England during World War II against Germany

- American troops and aircraft were deployed into Korea, Vietnam and into the neighbouring region

- aircraft of the American-led Coalition were deployed into the Middle East (mostly into Saudi Arabia) during the war against Iraq in 1990-1991

- NATO aircraft were forward based in countries of alliance around former Yugoslavia in 1999

- NATO aircraft were forward deployed into Sicily during Operation Unified Protector, against Muammar al Gaddafi's regime in Libya

Kenneth E Boulding, Conflict and Defense: A General Theory (Auckland: Valmy Publishing, 2018).

Kenneth E Boulding, The Meaning of the Twentieth Century: The Great Transition (London: George Allen \& Unwin, 1964). 


\section{Current NATO air power projection in Northeastern Europe}

NATO's main strategic orientation is defence, collective defence of Alliance, its populations and borders. In case of perceived threat to NATO members, consultations and mutual support activities in reassuring threatened members of Alliance, boosting collective defence capabilities and deterring potential threat are the measures to be taken.

This part will present current NATO assurance and deterrence activities and operations which started in 2014, with sole focus on air operations and projection of NATO air power in the Baltic region, encompassing the area of Alliance's member states (Estonia, Latvia, Lithuania and Poland).

They are response to the changed security situation on NATO's eastern borders, caused by Russia's illegal annexation of Crimea, destabilisation and activities in eastern Ukraine, as well as with increasing of activities and concentration of Russian military forces near NATO's eastern borders. The initial response was limited to assurance measures activities; monitoring and providing eastern Allies land, maritime and air picture, conducting interoperability driven exercises and assisting in the development of particular military capabilities. Further increase in Russia's military training activities near eastern NATO borders, violations of airspace, hybrid warfare activities, information and psychological operations, cyberattacks, propaganda in Northeastern European countries of Alliance, occurred and are ongoing. ${ }^{17}$

This has led to an intensification of the Alliance's activities in deterring potential threats. The number of NATO military exercises within Allied territory increased accompanied by the deployment of NATO multinational ground forces.

Conduct of NATO naval and particularly air force activities, projecting air power in the area was intensified since 2014, as well. Current NATO air power elements and activities are: ${ }^{18}$

1. Baltic Air Policing mission with task of protecting the airspace of the Baltic States (Estonia, Latvia, Lithuania and Poland). It is a collective (Allied) multinational continuous Air Forces presence, consisted of fighter aircraft and crews, which are reacting rapidly in case of airspace violations with interception and redirection out.

- The air squadrons of participating NATO member states are deployed on a rotational basis, and are permanently present at three military air bases in Estonia (Amari), Lithuania (Šiauliai) and Poland (Malbork).

2. Joint Intelligence, Surveillance and Reconnaissance mission over Baltic states, with the aim of providing timely information and intelligence to NATO political and military structure.

- Aerial assets in use: Alliance Ground Surveillance (AGS) system and Airborne Warning and Control System (AWACS) aircraft.

17 Mariusz Fryc, 'From Wales to Warsaw and Beyond: NATO’s Strategic Adaptation to the Russian Resurgence on Europe's Eastern Flank', Partnership for Peace Consortium of Defense Academies and Security Studies Institutes Connections Quarterly Journal 15, no 4 (2016), 45-65.

$18 \quad$ NATO, 'Deterrence and defence', s. a.; NATO, 'Baltic Air Policing', s. a. 
3. Airborne Warning and Control System (AWACS) patrols over Eastern Europe mission with task to patrol the skies over Eastern Europe and provide early warning in case of violations of Allied airspace.

It should not be neglected that the existence of air bases with accompanying units and the further additional national and Allied investments in their capability to receive and service modern air components, such as in air bases in Estonia, Lithuania and Poland, are important contributions to air power projection, too. ${ }^{19}$

Since the beginning of the implementation of Baltic Air Policing, there have been frequent violations of Allied airspace in the Baltic region by Russian aircraft. In certain cases, Russian civil aircraft were also involved in these incidents during establishing connections between mainland Russia and the Russian exclave of Kaliningrad, which is located between Lithuania and Poland. As violations occurred, they were intercepted and diverted out of space by the NATO air forces. In addition to these air force actions, NATO's political and diplomatic activities with the Russians followed, resulting in Russian announcements of civilian flight plans, and to some extent in a reduction in airspace violations. ${ }^{20}$ The main effect of Baltic Air Policing is the constant presence in Allied airspace and the demonstration of air power (in this case in synergistic action with radar systems as well) and determination in the protection of airspace in any case of violation of the specified area.

The joint actions of all NATO's air power elements are in accordance with NATOdefined roles, namely maintaining control of airspace, its inviolability, permanent security, and gathering valuable intelligence on a potential adversary, including those from the cyber domain, in order to defend against or prevent the hybrid action of the potential opponent. An additional activity and contribution of these air elements is the continuous participation in joint exercises with the components of NATO ground and naval forces in the area, which increases interoperability in operations and strengthens joint, collective defence capabilities.

\section{Conclusion}

The fundamental determinants of air power are of utmost importance for the establishment of sovereignty in the airspace in all conditions, with the purpose of achieving overall national and collective security and defence.

The ability to act rapidly, at long distances and from heights and distances against potential threats, as well as the ability to operate against targets in the air, on land surface and at sea are not inherent in any other military component.

19 Elisabeth Braw, 'NATO’s New Frontlines: Security and Deterrence in the Baltic Sea Region', Atlantic Council, November 2016; Lithuanian Armed Forces, 'NATO Air Policing Mission - Baltic Air Policing', s. a.

20 Denitsa Raynova and Lukasz Kulesa, 'Russia-West Incidents in the Air and at Sea 2016-2017: Out of the Danger Zone?', European Leadership Network, October 2018; Thomas Frear, 'Lessons Learned?: Success and Failure in Managing Russia-West Incidents 2014-2018’, European Leadership Network, April 2018. 
The importance of air power was recognised by the emergence, development and effects of aviation by victors and losers in wars, both.

"Anyone who has to fight, even with the most modern weapons, against an enemy in complete command of the air, fights like a savage against modern European troops, under the same handicaps and with the same chances of success... The fact of British air superiority threw to the winds all the tactical rules which we had hitherto applied with such success. In every battle to come, the strength of the Anglo-American air force was to be the deciding factor." 1

Erwin Rommel ${ }^{22}$

Air power is essential for an effective response to potential threats from any domain. In addition to its first task which is the preservation and control of airspace, the effective integration of the air force during joint operations along with significant and unique combat support capabilities enables the successful conduct of military operations.

NATO is currently in a position to resist Russian hybrid activities, aggressive propaganda and cyberattacks, with associated demonstrations of military force and violations of the airspace of its members on the eastern borders of NATO, especially in the Baltic region. The main response to this perceived threat, in addition to the implementation of political and diplomatic measures, is the conduct of joint military activities and operations aimed at deterring potential aggression, of which air power projection is of utmost importance.

The air force is a vital operational potential nesting air power projection, whose action is interwoven with the actions of other components of the military force, which makes deterrence credible, and in case the deterrence fails, it would be, due to its characteristics and capabilities, the key element in delivering primary and continuous response in defending against any potential attack. ${ }^{23}$

\section{References}

Boulding, Kenneth E, The Meaning of the Twentieth Century: The Great Transition. London: George Allen \& Unwin, 1964. Online: https://doi.org/10.4324/9781003256960

Boulding, Kenneth E, Conflict and Defense: A General Theory. Auckland: Valmy Publishing, 2018.

Braw, Elisabeth, 'NATO’s New Frontlines: Security and Deterrence in the Baltic Sea Region'.

Atlantic Council, November 2016. Online: www.jstor.org/stable/resrep03480

Canadian Forces Aerospace Warfare Centre, 'Air Power Doctrine', in Royal Canadian Air Force Doctrine, 2015.

Curtis E LeMay Center, ‘Basic Doctrine’, in United States Air Force Doctrine. Maxwell, 2015.

21 Basil H Liddell-Hart (ed.), The Rommel Papers (New York: Harcourt, Brace and Company, 1953), $285-286$.

22 Field Marshall Erwin Rommel (1891-1944), former German military commander and strategist in World War II.

23 Rayk Hähnlein, 'Air Power. Credible deterrence and defence call for superior air forces. NATO has realised that', Security Policy Working Paper no 6 (2018). 
Frear, Thomas, 'Lessons Learned?: Success and Failure in Managing Russia-West Incidents 2014-2018’. European Leadership Network, April 2018. Online: www.jstor.org/stable/ resrep17423?seq=1\#metadata_info_tab_contents

Fryc, Mariusz, 'From Wales to Warsaw and Beyond: NATO’s Strategic Adaptation to the Russian Resurgence on Europe's Eastern Flank'. Partnership for Peace Consortium of Defense Academies and Security Studies Institutes Connections Quarterly Journal 15, no 4 (2016), 45-65. Online: https://doi.org/10.11610/Connections.15.4.03

Hähnlein, Rayk, 'Air Power: Credible deterrence and defence call for superior air forces. NATO has realised that'. German Federal Academy for Security Policy, Security Policy Working Paper no 6 (2018). Online: www.jstor.org/stable/pdf/resrep22201. pdf?refreqid=excelsior\%3A81c607511bf4e3276a2bad37984ff7a4

Jones, Johnny R, Lieutenant Colonel, ‘Air Power’. United States Air University Journal. Online: www.airuniversity.af.edu/Portals/10/ASPJ/journals/Chronicles/jjones.pdf

Kainikara, Sanu, 'What Constitutes Air Power?', in Pathfinder Collection Volume 9, ed. by Sanu Kainikara. Canberra: Australian Air Power Development Centre, 2019, 23-26. Online: https:// airpower.airforce.gov.au/publications/pathfinder-collection-volume-9

Liddell-Hart, Basil H, The Rommel Papers. New York: Harcourt, Brace and Company, 1953.

Lithuanian Armed Forces, 'NATO Air Policing Mission - Baltic Air Policing', s. a. Online: https:// kariuomene.kam.lt/en/structure_1469/air_force/nato_air_-_policing_mission.html

Mueller, Karl P, ‘Air Power’, in RAND Project Air Force. John Wiley and Sons, Ltd., 2010. Online: www.rand.org/pubs/reprints/RP1412.html

NATO Allied Joint Publication, 'Fundamentals of Joint Air Power', in NATO Standard AJP3.3. Allied Joint Doctrine for Air and Space Operations, Edition B Version 1. NATO Standardization Office, 2016, 1-2, 1-1-1-18.

NATO, ‘Baltic Air Policing’, s. a. Online: https://ac.nato.int/missions/air-policing/baltics

NATO, 'Deterrence and defence’, s. a. Online: www.nato.int/cps/en/natohq/topics_133127.htm

Raynova, Denitsa and Lukasz Kulesa, 'Russia-West Incidents in the Air and at Sea 2016-2017: Out of the Danger Zone?’. European Leadership Network, October 2018. Online: www.jstor.org/ stable/pdf/resrep22133.pdf?refreqid=excelsior\%3A478e308f1a3de47bb6054f6a3bd1471c

Royal Australian Air Force Air Power Development Centre, 'Fundamentals of Air and Space Power', in The Air Power Manual. Australian Air Publication, 2013, 121.

UK Ministry of Defence's Development, Concepts and Doctrine Centre, 'An introduction to UK air power’, in Joint Doctrine Publication 0-30 UK Air and Space Power, $2^{\text {nd }}$ Edition, 2017. 